\title{
European Borderlands, Beyond Britain and Brexit
}

\author{
Thomas M. Wilson \\ Binghamton University; State University of New York
}

\begin{abstract}
Brexit, i.e., the United Kingdom's departure from membership in the European Union, has posed particular problems for communities in the borderlands of Northern Ireland since the referendum which began the process. With reference to initial scholarly assessments of Brexit effects in the UK and in other parts of Europe, the article explores the possible impact of Brexit on European borderlands. This article summarizes some of these problems in Northern Ireland in order to ask questions which may prove relevant at borders elsewhere in Europe, particularly in regard to issues of political, economic, social and cultural integration and differentiation in national and transnational contexts.
\end{abstract}

Key-words: Brexit, United Kingdom, Ireland, European integration, Borderlands

Brexit, i.e., the exit of the United Kingdom (UK) from the European Union (EU), has largely occurred, but is still not complete. Trade and other international relations between the United Kingdom and the EU have yet to be finalized in 2021, as may be seen in the continuing debate about the customs border in the Irish Sea, and many of the effects of Brexit in the UK, the Republic of Ireland (ROI) and the wider EU will take some time to be recognized, let alone acted upon. Nevertheless, there have already been 'Brexit effects' throughout the UK and ROI. While all of the peoples of the British Isles will be affected by Brexit, directly or indirectly, in the short and long-term, Brexit effects are already apparent in the borderlands, i.e., the land border that simultaneously divides and conjoins the ROI and Northern Ireland, a constituent part of the UK. This international border was first established upon the partition of Ireland in 1921, and its $499 \mathrm{~km}$ (310 mi) separates the 26 counties of the ROI from the six counties of Northern Ireland.

County Armagh, where I have conducted intermittent ethnographic research since 1990, is a county famous for its role in the armed nationalist struggle, known locally as 'the Troubles', which lasted from 1968 to 1998. Armagh, in Northern Ireland south-west of Belfast (Northern Ireland's capital), is divided between its Protestant population, mainly residing in the county's north, and its Catholic population in the south. Since the original UK referendum which initiated Brexit, the plans and realization of the UK's departure from the EU have presented many challenges, often perceived as direct threats, in South Armagh, not only because of the latter's longstanding support of Irish republicanism in general and the IRA in particular, but because of the many benefits which have accrued in the county from Northern Ireland's membership in the EU. 
The general nature of these perceived challenges to the quality of life of the people of South Armagh, challenges which affect the quotidian conditions of work, travel, health, and leisure in the borderlands, have been reviewed elsewhere (Wilson 2019, 2020b) and are matters of considerable daily concern in Ireland. Less apparent are some of the reasons why Brexit may resonate in other European borderlands, and among scholars of these borderlands beyond the UK and Ireland, at, for example, international borders in Eastern and Southeastern Europe. This article introduces some of the issues that are palpable in Northern Ireland's borderlands today which may also be of concern, and thus worthy of more ethnographic attention, in European borderlands seemingly beyond Brexit and the UK.

\section{Brexit matters in Ireland}

Brexit has become, in its short five-year span, a matter of daily and widespread significance in Ireland and Britain. In general public discourse it has come to refer to the referendum of June 2016 which kickstarted the overall exiting process, but it is also a referent to the political, economic and regulatory processes needed to see the departure through to completion, and to the actual moment or event when the UK left the EU on 31 January 2020. ${ }^{2}$ In South Armagh, however, many local people, when discussing Brexit with me in my ethnographic research during the summers of 2017 to 2019, also opined how Brexit was a shock to European integration in general, and thus also something sure to affect diverse populations across the continent. Most often raised by my respondents, as examples of communities of particular vulnerability to the wider Brexit effects in Europe, were farmers, consumers, and political parties and movements seeking both the benefits of European integration and the strengthening of regional and national identities and cultures. The significance of many of these aspects of the local experience of European integration, as for example in seeking EU benefits and claiming and reinforcing regional identity, is something that is presumed in Northern Ireland to be shared with many areas which are on the edge of the European bloc.

It was thus also not surprising to me that many of the discussions I had with local respondents in South Armagh turned to a consideration of the Brexit effects in other borderlands. ${ }^{3}$ In this regard it was clear to me and to some of my interlocutors in Ireland that Brexit either had or would become a symbol beyond Ireland and Britain of national constituencies and their continuing relationship to the EU, involving such matters as national austerity, sovereignty, authority and control. The Irish nationalists of South Armagh with whom I spoke about Brexit, most of whom have been supporters of Irish republicanism and opponents of British unionism, ${ }^{4}$ recognized that the general disgruntlement among the electorate in the UK seems to have parallels among other populist and regional movements across the continent. They saw that Brexit, while clearly anti-EU in spirit, nonetheless reflects many similar political movements on the continent. Thus, Brexit also is a marker of many things about European integration that are somewhat contradictory. For example, in the UK some Brexiteers seek less government control, through government downsizing, more 
deregulation of the economy, and a return to the days of British insular sovereignty, while other Brexiteers want greater control, as in the long-lost days when British, mainly English, elites controlled the centralized, hierarchical and bureaucratized state. One might be forgiven for viewing the calls for greater freedom to pursue the benefits of a free and deregulated market as potential support too for illiberalism, perhaps bordering on fascism. This was clearly on the minds of some of my republican respondents in South Armagh, who were alarmed at the rise of illiberalism in places like Poland and Hungary, such as that described by Kürti (2020).

The contradictions of Brexit in daily life in Northern Ireland are significant, and apparent to many local people. While Brexit throughout the UK seems to have roots in the call to take back control from an undemocratic Brussels, it has been that supposed distant and faceless EU that has helped Northern Ireland achieve unprecedented prosperity and social welfare over the last quarter century. As some local republican politicians have pointed out to me, a strong British state was a repressive one, and the de-regulation of the economy as desired by so many Brexiteers may have the opposite effect of re-centralizing the British state and subverting decades of political devolution across the UK. This prospect also suggests to people in South Armagh that a revitalized and resecuritized British state would mean a re-militarized Northern Ireland, and a possible return of 'the Troubles' (Wilson 2019).

This is not a future that many in South Armagh would welcome, because at the very least Brexit may be a harbinger of a return to new or revitalized forms of nationalism, threatening the transnationalism that has become part of local border life for decades. Unlike the multiple and fluid identities of migrants recognized by scholars of borderlands elsewhere (Nitsiakos 2010), this transnationalism in Northern Ireland has arisen among its residents, who have embraced multilevel and supranational governance and shared sovereignty, established between the ROI and UK in the Belfast Good Friday Agreement of 1998 (GFA) that began the formal end of the recent Troubles. Brexit in fact may eventually put an end to the transnational governance that was set up under the GFA, stopping at least some of the new forms of political cooperation between the two national governments that were created in the wake of the GFA. Brexit will also certainly change cross-border relations of all sorts, including the disruption of an all-island economy that has taken shape over 50 years of cross-border community cooperation, trade, and legal integration under the umbrella of the EU. In addition, Brexit is forcing the people of Northern Ireland to publicly reconsider how their national and European identities interrelate (Wilson 2020b).

Over the last few decades this last consideration, of the Brexit effects on identities in the Northern Ireland borderlands, has become more significant. This is because the people of the Northern Ireland borderlands have developed, or have begun to articulate, a new form of European identity that is less instrumental than what was once widely demonstrated and perceived (Wilson 2000, 2007). Local identity now seems to be much more affective, suggesting to me that a widespread "banal Europeanism" (Cram 2009) has taken root there (Wilson 2020b). In the 1990s, in an earlier research project, I concluded that Armagh borderlanders, like most people in Northern Ireland, demonstrated little affective identification with the EU (Wilson 2000a, 2000b; McGowan 
and O'Connor 2004), as their national identity was clearly primary and any related notion of a European identity decidedly secondary. Today, there is a greater acceptance of European identity as a complement to national identity, at a level and intensity that may not match national identity but has risen in significance. While Brexit may be a platform to perform or confirm a European identity, my respondents over the last four years have persuaded me that this is not exclusively strategic, but an accurate reflection of the changing conditions of borderland culture and identity, where for some even remaining within a UK within the EU might be acceptable, to people who for generations stumped and fought for a united Ireland.

Contradictions aside, a few facts and figures will indicate some of the societal changes that have developed over the last few decades that have influenced the strong opposition to Brexit to be found in the borderlands of Northern Ireland, as first seen in the 2016 vote to remain in the EU. ${ }^{5}$ Politically and economically, the EU, through direct and indirect funding and political support, helped to broker the GFA, reinvigorate Northern Ireland's infrastructure, revitalize the economy, and liberalize political culture across the whole island, leading to greater political empowerment and a more equitable justice system for groups who had long argued that the Northern Ireland statelet, established in 1921, was sectarian, racist and patriarchal. European integration has also allowed Irish nationalists and republicans a greater presence and voice on the global scene, where they have continued their struggle for human rights and against the injustices which in their view they suffered at the hands of unionists in a British colonial state (Wilson 2019).

The GFA of 1998 helped to create new avenues for cross-border and transnational governance between the ROI and UK and between Northern Ireland and other UK regions. These new lines of cooperation and communication have brought the relevant parties closer together on matters related to trade, business development, food safety, agriculture, health, transport, education, and the environment. The Northern Ireland borderlands have seen great improvements in tourism, agricultural efficiency and marketing, local community cultural programs, and local, regional and transnational networking (Wilson 2000a, 2007). In the EU funding cycle of 2014-2020, Northern Ireland farmers alone will have received, through EU guaranteed prices, markets and subsidies, approximately $€ 2.3$ billion, and the EU was committed overall to investments of $€ 3.5$ billion, in a region of 1.8 million people (Eurolink 2018). Perhaps most important to the borderlands of Northern Ireland is the EU's Programme for Peace and Reconciliation, which from 1995 to 2013 injected $€ 1.5$ billion into the border counties of Northern Ireland and the ROI (McCall 2014, 207), and in 2014-2020 was expected to have brought $€ 229$ million to the region.

This peace dividend has been a symbol of the joint commitment by the EU, UK and ROI to economic and social development in Northern Ireland in general, and to cross-community dialogue and cooperation between nationalists and unionists in Northern Ireland. It is safe to say that Brexit has come to symbolize very different forms of political and economic pragmatism and realism in Northern Ireland, in moves that are sure to subvert so much that was accomplished over the last generation that has achieved some degree of greater integration of polity, economy and society on the island of Ireland. 


\section{Brexit matters beyond Ireland}

Brexit has been perceived, feared and experienced in the Northern Ireland borderlands as a matter fundamental to future government, governance, economic development, civil and human rights, and national and European identity. As such it is also widely perceived there as being too significant to be bounded as a wholly, or even a mainly, internal affair, of importance in the UK and, perhaps to a lesser extent, in neighboring Ireland. The people of the South Armagh borderlands, including local community leaders, politicians, party activists, civil servants, business people and farmers, have also recognized Brexit's transnational and international dimensions, and have raised with me how Brexit's effects will have an impact in many European locales outside of Ireland and Britain. In this regard, and borrowing from the expressed critiques and concerns of Brexit as a European phenomenon which I encountered in Northern Ireland, it is worth considering whether Brexit will affect other European borderlands in terms of the neo-liberalization of the state, the rise of new neo-nationalists movements, the heightened sensitivity to issues regarding security, and the role Brexit may play concerning changing issues of European identity.

In regard to the last issue, and based on my research in Northern Ireland, it seems prudent to ask if Brexit will have any particular salience elsewhere in Europe when examining issues of political identity at and across international borders. This might be of continuing significance when matters of national identity, ethnic affiliation, social commensality and economic cooperation and competition are seen to play roles in integrating, differentiating and dividing borderland communities, both within nation-states and across borderlines. Simply put, the question posed to me by South Armagh borderlanders, and one I think has salience in other regions of Europe, is: will Brexit matter in the lives of many diverse peoples, from the Urals to Iceland, from Iberia to Karelia, including border residents, workers and travelers, in ways perhaps mirroring what Brexit has wrought in the Northern Ireland borderlands? Perhaps nowhere is this more apparent than in areas of longstanding ethnic and national tensions, in regions such as Eastern and Southeastern Europe, where, for example, constituent nations seceded from the Yugoslavian union a generation before Brexit (Hayden 2020), and where today many historical and contemporary forces continue to revise collective notions of how hard and how soft international borders and border peoples can be.

But what will kickstart or motor identity change, political allegiances and electoral and legislation support for European membership and integration, in any particular place in Europe and across international borders? Brexit is sure to have an effect on regional economic development across the continent, and the evidence for this is growing (Henry and Smith 2021). Brexit has already had an impact on direct foreign investment into Europe, with investors like Japan moving out of the British market in favor of new continental opportunities, if the location and dimensions of Japanese investment is an indication (Cieślik and Ryan 2021). Many in Europe will feel the impact of Brexit on banking and other financial centers, with some apparent winners, such as Amsterdam and Dublin, at the expense of London, reflecting at least some fragmentation in financial services in the near future (Heneghan and Hall 2021). Brexit has also highlighted issues 
of exclusion and inclusion in regard to national and European identities. While in Northern Ireland there has been increasing evidence that, at least in Irish nationalist areas, both national and European identities can nest easily with each other (Wilson 2020b), supporting a growing atmosphere of "banal Europeanism" (Cram 2009), Euroskepticism and a rejection of alleged EU interference in everyday life seems to be rising at a rate in some locales in Central and Eastern Europe that may dwarf any pro-EU sentiments like those I have witnessed in South Armagh.

However, conclusions such as these, as reached by ethnographers such as me, even if based on a generation of research, must face the reality of the emotional impact and residue of events and processes like Brexit, particularly on the dialogue between and among regions, nations, states and the EU. Because it is apparent to many of its critics, whether nominal supporters or opponents, that the overall course of European integration is twisty and fragile, it is equally apparent that perturbations such as COVID and Brexit bear continuous and multidimensional surveillance. Brexit may come to symbolize one aberrant event in the European integration process of ever closer union, or it may have greater, as yet unknown, significance. As Robert Hayden (2020) recently suggested, the impulse to leave the wider political union that was Yugoslavia had many short- and long-term causes, some of which did not seem so significant in their first realization. At the heart of Brexit is the continuing love and hate relationship Europeans have with their own nationalisms and regionalisms (Hedetoft 2020), all of which have related border dimensions.

While the Brexit negotiations between the EU and the UK have in many respects been concluded in 2021, many matters regarding trade remain outstanding. This became apparent in the emotional wrangling over the UK-EU deals on COVID vaccine (Landler 2021), an example of many other trading tensions that arose seemingly before the metaphorical ink on the agreements regarding the UK's departure dried. While some matters seemed to have been agreed to the satisfaction of all parties, the trade dispute over vaccine highlighted too that even Northern Ireland's status as a liminal borderland between the EU and the UK will be a constant source of debate and negotiation going forward. This leaves Northern Ireland in a state it is well used to, as a political football to be passed back and forth within and between the British, Irish and EU governments, and various constituencies within Northern Ireland, as evident in the continuing social unrest among members of the unionist community in Northern Ireland over the single market border in the Irish Sea, established as part of the Brexit deal between the UK and the EU.

It is not surprising that my research, and a vast range of journalist and governmental assessment, concludes that Brexit is a matter of significant daily concern in the borderlands of Northern Ireland today, and promises to continue as such for the foreseeable future. These concerns about Brexit involve the potential if not probable decline in economic well-being, as part of the predicted changes in levels and types of governmental subvention and direct foreign investment, the diminishing if not the loss of the freedoms associated with the EU single market and customs union, and the mobility of labor as European citizens. Brexit also threatens to transform the transnational governance that has for the last generation helped maintain the peace. ${ }^{6}$ 
Brexit is an Irish and British crisis, not unlike other crises that have beset the course of European integration since its formal beginnings in the 1950s. Brexit is also a signpost on that journey, highlighting for many people in Northern Ireland how the EU has been a palpable force in their everyday lives. Brexit already seems to be yielding a sense of loss that borderlanders with whom I have interacted these past few summers fear will grow with time. In the Northern Ireland borderlands Brexit is clearly perceived as a crisis for Ireland, but also one for Europe (Wilson 2010). They are aware that Brexit has become a sign of the times to many other European peoples, especially those who have become more Euroskeptical, and more dissatisfied with the EU's failure to reduce income inequalities in and among the member states, and raise their incomes and standard of living. This dissatisfaction has been intensified by the recent jolts to European integration delivered by the migration crisis, the COVID pandemic, and Brexit, which overall have greatly endangered many national and transnational notions of solidarity and democracy (Hadjimichalis 2021). This distancing from the people, centers and tenets of European integration has obviously exacerbated some longstanding opposition to EU membership to be found in some more recent member states since their accession, such as in Bulgaria (Ilieva and Wilson 2011), and in longer serving members, as may be witnessed in Greek moves to leave the EU in their own version of 'Grexit' (Petrakos and Sotiriou 2021), and in the current (October 2021) row between the EU and Poland. The "exititis" about which Hayden (2020) cautions us all may be catching, in the Brexit political pandemic that has drawn many peoples and governments back to the perceived necessity of harder borders and even harder national regimes.

\section{Conclusion}

In a recent publication I argued that Brexit should matter to ethnographers and anthropologists elsewhere in Europe, beyond the borders of the UK and Ireland (Wilson 2020a). Less clear to me is the impact Brexit will have on border and other communities in the EU and its neighbors. While Brexit has caused a seismic shift in internal relations within, and external relations between, the UK and ROI, the question remains as to its repercussions across Europe, within and beyond the EU. While many specific Brexit effects may be obscure at this stage, it is already certain that they will affect global geopolitics and geo-economics in a variety of significant ways. While the overall 'Brexit effects' in the borderlands of Northern Ireland, particularly in South Armagh, have been immediate, emotional, and deep, it is also apparent that in many if not most parts of the wider Europe many people have been relatively unconcerned and unaffected, seeing Brexit as largely a foreign matter internal to the UK and/or a matter for European elites. I wager that the people of the borderlands of Eastern and Southeastern Europe, like many other peoples in Southern, Central and Northern Europe, do not see Brexit as a matter of concern. But this notion reflects something a shopkeeper said to me in Armagh in 2019, when he lamented the probability that Brexit would lead to a return of a hard border, which in his words would 'bring back the fences that will keep out the tourists.' When I mentioned in response that I had recently returned from a research trip to 
the Finnish-Russian borderlands, he opined that Brexit was not the only source of fences going up, and he concluded that 'even in a democracy you sometimes need fences, so why should anyone outside Ireland worry about Brexit?'

This article has cautioned against this skeptical stance, and calls for more vigilance outside the UK about Brexit. Brexit is part of a wider continental movement among many peoples of various political persuasions to take back control from 'Europe' in order to regain or bolster a perceived loss of national sovereignty. These issues, related to national concerns about migration, citizenship and state roles in safeguarding security and national welfare, are the veritable stuff of borderland life, the lives of borderlanders, and the role the border plays in national imaginaries. At the very least the contradictions represented by the Brexit process contribute to the already complicated contradictions of region, nation and state that bedevil all European borders (Anderson and O'Dowd 1999). With illustrations from Northern Ireland, this article has suggested some ways in which Brexit may have significance beyond the borders of the UK because it has highlighted many of the forces which will infuse matters of national and European integration and division across the continent. While the EU has played a positive role in so much that matters in everyday life in the Northern Ireland borderlands, the EU as a capitalist generator of neoliberalization may be having an equally negative effect in borderlands elsewhere in Europe. But the multiple dimensions of European integration are often in stark form in borderlands, and in this article I question to what extent Brexit will be seen less as a British and more as a European phenomenon in the future.

The Irish border has for a century been a thorny issue for Britain. Brexit has now made the Irish border an EU problem, and Brexit an issue beyond Britain and its borders. While Brexit will now entail a 're-bordering' of the Northern Ireland border region after decades of "de-bordering" (Anderson 2018), it will also intensify the relocation of other European borders, continuing processes that predated it (Green 2013). Only time will tell what role Brexit will play in rebordering or de-bordering the regions, nations and states of Eastern Europe.

\section{Notes}

${ }^{1}$ This article considers some ways that ethnographers of European borders might benefit from a closer look at what Brexit has done and what it means in the Northern Ireland borderlands. It and I owe a debt to the organizers and leaders of the Konitsa Summer School in the Anthropology of the Balkans, co-sponsored by the Border Crossings Network, where I presented a first version of this paper in 2017. My sincere and warm thanks to all those who participated in that summer school, including faculty, administrators and students, but my particular thanks are due to Professor Vasilis Nitsiakos and Dr. Ioannis Manos for their guidance, patience and overall exemplary hospitality. My thanks go also to my co-editor of this special issue of AEER, Davide $\mathrm{N}$. Carnevale, and to the journal's referees who recommended changes to this article that substantially improved it. 
${ }^{2}$ For a review of how Brexit has been perceived among British people in the UK and elsewhere in Europe, see MacClancy $(2019,369)$. Brexit also presents major problems to European citizens and other migrants in and to the UK (Reed-Danahay 2020), who have had many similar, and some dissimilar, ideas about Brexit to those of their British neighbors.

3 This article is intended as an introduction to some of the issues that are of concern to borderlanders in Northern Ireland in regard to Brexit. It is not a comprehensive analysis of my ethnographic research on Brexit in the region, which is ongoing and at this point as open-ended as Brexit itself. Nonetheless, this essay is based on approximately 54 interviews I conducted, in semistructured and conversational environments in the summers of 2016 to 2019, with Northern Ireland elected representatives, party officers, activists and supporters of Sinn Féin (32 of the interviews conducted) and the Democratic Unionist Party (8). These discussions also included other residents and citizens of Northern Ireland who did not identify with those two parties or support them in any formal or public role. This research relied too on contacts I made in previous projects in these borderlands. In 2016-2019 my research included elected government representatives, political party members, farmers and their families, shopkeepers/publicans, professionals in service-related positions (such as solicitors, financial advisors, clergy), the workers and managers of a major heritage/community center, and other residents of the border region, some of whom were blue collar employees or on the dole. I also acknowledge with thanks that the research on which this article is based was funded by a Mileur Fellowship of Harpur College of Binghamton University (summers of 2016 and 2017), and by the Wenner Gren Foundation for Anthropological Research (summer, 2019).

4 The two principal communities (Coulter 1999) in Northern Ireland are usually identified as Irish nationalists and British unionists. The former identifies mostly with the Roman Catholic Church and faith, the latter with various forms of Protestantism. In South Armagh most nationalists have supported in some ways Irish republicans, some of whom in the past have used violence to attempt to achieve the political unity of the Irish nation. The largest and most significant Irish nationalist paramilitary group is the Irish Republican Army (IRA). British unionists want to keep Northern Ireland a constituent region of the UK. Loyalists are those unionists who are loyal to the British crown and way of life, and their associated paramilitary groups also adopted violence, but in their case as a strategy to maintain the union of Northern Ireland and the rest of the UK.

${ }^{5}$ On 23 June 2016 in a close vote the people of the UK in a national referendum elected to leave the EU. This vote for 'Brexit', i.e., the British exit from the EU of 28 member states, revealed major regional differences in British responses to the 'Europe' of the EU and to the forces of Europeanization it has brought. Scotland, Northern Ireland and the London capital region voted to remain in the EU while most of the rest of England and Wales voted to leave. Since 2016 Northern Ireland has been at the center of the debate on the shape of the UK after Brexit.

${ }^{6}$ For analyses of these developments in economics and politics in Northern Ireland that are linked to European integration, see O'Dowd and McCall 2008; Shirlow and Coulter 2014; Morrow and Byrne 2017; McCall 2001, 2011, 2014; McGowan and O’Connor 2004; Murphy 2018). 


\section{References}

Anderson, James. 2018. "Ireland's Borders, Brexit Centre-Stage: A Commentary." Space and Polity 22, no. 2: 255-269.

Anderson, James, and Liam O'Dowd. 1999. "Borders, Border Regions and Territoriality: Contradictory Meanings, Changing Significance.” Regional Studies 33, no. 7: 593-604.

Cieślik, Andrzej, and Michael Ryan. 2021. "Brexit and the location of Japanese direct investment in European regions." European Urban and Regional Studies 28, no. 1: 66-73.

Coulter, Colin. 1999. Contemporary Northern Irish Society: An Introduction. London: Pluto Press.

Cram, Laura. 2009. "Introduction: Banal Europeanism: European Union Identity and National Identities in Synergy." Nations and Nationalism 15, no. 1: 101-108.

Eurolink. 2018. "EU Funding in Northern Ireland." Accessed 10 October 2018. www.eurolink-eu.net/eu-funding-2/

Green, Sarah. 2013. "Borders and the Relocation of Europe." Annual Review of Anthropology 42: 345-361.

Hadjimichalis, Costis. 2021. "An uncertain Future for the Post-Brexit, Post-COVID-19 European Union." European Urban and Regional Studies 28, no. 1: 8-13.

Hayden, Robert M. 2020. "EXITitis in Europe? Yugoslavia as the First European Disunion." Ethnologia Europaea 50, no. 2: 49-61.

Hedetoft, Ulf. 2020. "Brexit: A Valediction. Forbidding Mourning." Ethnologia Europaea 50, no. 2: 80-87.

Heneghan, Martin, and Sarah Hall. 2021. "The emerging geography of European financial centres: Fragmentation in the European Union and concentration in the UK?" European Urban and Regional Studies 28, no. 1: 40-46.

Henry, Nick, and Adrian Smith. 2021. "Europe and/or the UK: Post-Brexit Urban and Regional Development Futures. A Special Issue.” European Urban and Regional Studies 28, no. 1: 3-7.

Ilieva, Polya, and Thomas M. Wilson. 2011. "Euroscepticism and Europeanization at a Margin of Europe." Anthropological Journal of European Cultures 20, no. 2: 87-113.

Kürti, László. 2020. "Orbánism: The Culture of Illiberalism in Hungary.” Ethnologia Europaea 50, no. 2: 62-79.

Landler, Mark. 2021. "Johnson Wins Vaccine Spat with E.U., but a Struggle over Northern Ireland Looms." New York Times, February 4, 2021. www.nytimes.com/2021/02/04/world/europe/johnson-uk-eu-vaccine.html

MacClancy, Jeremy. 2019. "Before and Beyond Brexit: Political Dimensions of UK Lifestyle Migration." Journal of the Royal Anthropological Institute (N.S.) 25, no. 2: 368-389.

McCall, Cathal. 2001. "The Production of Space and the Re-alignment of Identity in Northern Ireland." Regional and Federal Studies 11, no. 2: 1-21.

McCall, Cathal. 2011. "Culture and the Irish Border: Spaces for Conflict Transformation." Cooperation and Conflict 46, no. 2: 201-221. 
McCall, Cathal. 2014. "European Union Cross-Border Cooperation and Conflict Amelioration." Space and Polity 17, no. 2: 197-216.

McGowan, Lee, and Julia S. O'Connor. 2004. "Exploring Eurovisions: Awareness and Knowledge of the European Union in Northern Ireland." Irish Political Studies 19, no. 2: 21-42.

Morrow, Duncan, and Jonny Byrne. 2017. "Northern Ireland after Brexit: A Fragile Peace Put in Jeopardy." London School of Economics Brexit Blog, January 11, 2017. blogs.lse.ac.uk/brexit/2017/01/11/northern-ireland-after-brexit-a-fragile-peace-put-in-jeopardy/

Murphy, Mary C. 2018. Europe and Northern Ireland's Future: Negotiating Brexit's Unique Case. Newcastle Upon Tyne: Agenda Publishing.

Nitsiakos, Vassilis. 2010. On the Border: Transborder Mobility, Ethnic Groups and Boundaries on the Albanian-Greek Frontier. Berlin: Lit Verlag.

O'Dowd, Liam, and Cathal McCall. 2008. "Escaping the Cage of Ethno-national Conflict in Northern Ireland: The Importance of Transnational Networks." Ethnopolitics 7, no. 1: 81-99.

Petrakos, George, and Alexandra Sotiriou. 2021. "Grexit and Brexit: Incidents, Accidents and Wake-up Calls on the Bumpy Road of European (Dis)integration." European Urban and Regional Studies 28, no. 1: 20-25.

Reed-Danahay, Deborah. 2020. "Brexit, Liminality, and Ambiguities of Belonging: French Citizens in London." Ethnologia Europaea 50, no. 2: 16-31.

Shirlow, Peter, and Colin Coulter. 2014. "Northern Ireland: Twenty Years after the Ceasefires." Studies in Conflict and Terrorism 39, no. 9: 713-719.

Wilson, Thomas M. 2000. "The Obstacles to European Union Regional Policy in the Northern Ireland Borderlands." Human Organization 59, no. 1: 1-10.

Wilson, Thomas M. 2007. "Europeanisation, Identity and Policy in the Northern Ireland Borderlands." In Geopolitics of European Union Enlargement: The Fortress Empire, edited by Warwick Armstrong and James Anderson. London: Routledge.

Wilson, Thomas M. 2010. "Crisis: On the Limits of European Integration and Identity in Northern Ireland." In Human Nature as Capacity: Transcending Discourse and Classification, edited by Nigel Rapport. New York and Oxford: Berghahn Books.

Wilson, Thomas M. 2019. "Old and New Nationalisms in the Brexit Borderlands of Northern Ireland." In Cycles of Hatred and Rage: What Right-Wing Extremists in Europe and Their Parties Tell Us About the U.S., edited by Katherine C. Donahue and Patricia Heck, 25-51. London: Palgrave MacMillan.

Wilson, Thomas M. 2020a. "Anthropological Approaches to Why Brexit Matters. Introduction to Special Issue.” Ethnologia Europaea 50, no. 2: 7-15.

Wilson, Thomas M. 2020b. "Fearing Brexit: The Changing Face of Europeanization in the Borderlands of Northern Ireland." Ethnologia Europaea 50, no. 2: 32-48. 